\title{
IAMJ
}

INTERNATIONAL

AYURVEDIC

MEDICAL JOURNAL

\section{MANAGEMENT OF ISCHEMIC HEART DISEASE AS PER AYURVEDA: A REVIEW}

\author{
Gitismita Borah ${ }^{1}$, Satyendra Ojha ${ }^{2}$ \\ ${ }^{1} \mathrm{MD}$ (Ayu), Dept. of RogaNidan, Govt. Ayurvedic College, Guwahati-14, Assam, India \\ ${ }^{2}$ Chief consultant, Ayurcosmo Hospital, Vishrambagh Sangli, Maharastra, India
}

Corresponding Author: borahgeet91@gmail.com

\section{https://doi.org/10.46607/iamj4009102021}

(Published Online: October 2021)

Open Access

(c) International Ayurvedic Medical Journal, India 2021

Article Received: 30/09//2021 - Peer Reviewed: 07/10/2021 - Accepted for Publication: 10/10/2021

\section{Check for updates}

\begin{abstract}
Ischemic heart disease has emerged out as one of the alarming health concerns among both elderly and the young adults. Although breakthrough advances have been made in the field of medicine, a large number of mortalities related to ischemic heart disease have been reported in the past few years. This exerts pressure on finding an effective treatment module overcoming the challenges limiting effective control of the disease. Ayurveda has discussed extensively regarding the Hridrogas along with the various dietary, lifestyle modifications and treatment approaches that need to be employed for effective control of the disease. Vatikhridroga mentioned in Ayurveda holds a clear resemblance with ischemic heart disease. Correction of factors like Dhamanipratichaya and Grathitarakta in the pathogenesis of the disease needs to be emphasized while treating a patient with ischemic heart disease.
\end{abstract}

Keywords: Ischemic Heart Disease, VatikHridroga, DhamaniPratichaya, GrathitaRakta.

\section{INTRODUCTION}

IHD is the most common, serious, chronic, lifethreatening illness in the United States, where 13 million persons have IHD, > 6 million have angina pec- toris, and $>7$ million have sustained a myocardial infarction. Population subgroups that are particularly affected are men in South Asian countries, especially 
India and the Middle East. Ischemic Heart Disease (IHD) is a condition in which there is an inadequate supply of blood and oxygen to a portion of the myocardium; it typically occurs when there is an imbalance between myocardial oxygen supply and demand. The most common cause of myocardial ischemia is atherosclerotic disease of an epicardial coronary artery (or arteries) sufficient to cause a regional reduction in myocardial blood flow and inadequate perfusion of the myocardium supplied by the involved coronary artery. ${ }^{1}$ Chronic stable angina is the first presentation of ischemic heart disease in about $50 \%$ of patients ${ }^{2}$. Coronary atherosclerosis is the cause of angina pectoris in most patients.

In Ayurveda, cardiovascular diseases are described in many details as Hridroga. Description of Hridroga, including its various types along with the etiological factors, is clearly mentioned in all the Brihattrayees. Vataja Hridrog $a^{3}$ mentioned as per Ayurveda has got clear resemblance with episodes of Angina pectoris. Ayurveda has also advocated the diet and lifestyle to be adopted for prevention and management of Hridroga. The concept of "Dhamanipratichaya" which has been mentioned as a kaphajananatmajavikara as per $\mathrm{Charak}^{4}$, also holds great importance in relation to Atherosclerosis which is again one of the most common causes of ischemic heart disease (IHD).

This review outlines the pathogenesis and the disease-modifying factors essential for the management of IHD as per Ayurveda to help adopt an effective treatment approach for the management of the disease.

\section{Clinical Evaluation Of The Likelihood Of Coro- nary Artery Disease:}

Clinicopathologic studies have demonstrated that it is possible to predict the probability of CAD based on the history and the physical examination ${ }^{5}$. Chronic stable angina is the first presentation of ischemic heart disease in about $50 \%$ of patients. Angina is further labelled as stable when its characteristics have been unchanged over the preceding 60 days. Unstable angina is defined as angina that presents in one of three major ways: rest angina, severe new-onset angina or prior angina increasing in severity. ${ }^{6}$

\section{History ${ }^{7}$ :}

- The typical patient with angina is a man $>50$ years or a woman $>60$ years of age who complains of episodes of chest discomfort, usually described as heaviness, pressure, squeezing, smothering, or choking and only rarely as frank pain.

- When the patient is asked to localize the sensation, he or she typically places a hand over the sternum, sometimes with a clenched fist, to indicate a squeezing, central, substernal discomfort (Levine's sign).

- Angina is rarely localized below the umbilicus or above the mandible.

- A useful finding in assessing a patient with chest discomfort is the fact that myocardial ischemic discomfort does not radiate to the trapezius muscles; that radiation pattern is more typical of pericarditis.

Although episodes of angina typically are caused by exertion (e.g., exercise, hurrying, or sexual activity) or emotion (e.g., stress, anger, fright, or frustration) and are relieved by rest, they also may occur at rest and while the patient is recumbent (angina decubitus). The patient may be awakened at night by typical chest discomfort and dyspnoea. Nocturnal angina may be due to episodic tachycardia, diminished oxygenation as the respiratory pattern changes during sleep, or expansion of the intrathoracic blood volume that occurs with recumbency.

\section{Physical Examination"}

- The physical examination is often normal in patients with stable angina when they are asymptomatic.

- Clinicians should search for evidence of atherosclerotic disease at other sites, such as an abdominal aortic aneurysm, carotid arterial bruits, and diminished arterial pulses in the lower extremities.

- Evidence for the peripheral arterial disease should be sought by evaluating the pulse contour at multiple locations and comparing the blood pressure between the arms and between the arms and the legs (ankle-brachial index). 
- Examination of the fundi may reveal an increased light reflex and arteriovenous nicking as evidence of hypertension.

- There also may be signs of anaemia, thyroid disease, and nicotine stains on the fingertips from cigarette smoking. Palpation may reveal cardiac enlargement and abnormal contraction of the cardiac impulse (left ventricular dyskinesia).

- Auscultation can uncover arterial bruits, a third and/or fourth heart sound, and if acute ischemia or previous infarction has impaired papillary muscle function, an apical systolic murmur due to mitral regurgitation. These auscultatory signs are best appreciated with the patient in the left lateral decubitus position.

\section{Ayurvedic Review:}

\section{Nirukti:}

In Ayurveda, Hridaya is synonymous with the word heart. It is derived from three verbs (as per shatapatabrahman and brihadaranyak). "Hrun" denotes to abduct, "dad" means to donate and "in gatou" selfgenerated rhythmicity for contraction and relaxation. Hridaya is the essence of sonita and kapha, which is again the seat of Pranavahadhamanis. ${ }^{9}$ It is the moolasthana of pranavaha and rasavaha srotas. ${ }^{10}$ As per Charak, it is the seat of raktavahini dhamanis. ${ }^{11}$

\section{Doshik prevalence of hridaya:}

Prana Vayu: It is vital for the proper functioning of heart, mind and intellect. ${ }^{12}$

Vyanavayu: It is the force that helps in the circulation of rasa to the entire body. ${ }^{13}$

Sadhak pitta: This helps in the proper functioning of hridaya, and indirectly, influences proper functioning of the nervous system like intelligence etc. action of this dosa on hridaya appears to be psychophysiological. ${ }^{14}$

Abalambakkapha: Avalambakkapha provides the nourishment from annarasa to the heart and provides sustenance to other organs. It can be assumed to be the protein content of the intracellular and extracellular fluid systems of the body. ${ }^{15}$

\section{Hridroga:}

There are five varieties of hridrogas mentioned in Ayurveda I.e, Vataja, pittaja. Kaphaja, Sannipataja and Krimija ${ }^{16}$. Out of these five, the presentation of VatajaHridroga, specifically mimics angina pectoris.

\section{Vataja Hridroga ${ }^{16}$ :}

In this variety of hridroga, the pain has been presented as the primary clinical feature. It typically presents with palpitation, syncope, chest tightness etc.

Clinical features of Vataja Hridroga: ${ }^{16,17}$

\begin{tabular}{|c|c|c|c|}
\hline Ayurvedic term & English Term & Ayurvedic term & English Term \\
\hline Cardiac Symptoms: & & General Symptoms: & \\
\hline Ayamyate & Drawing pain & Vepathu & Tremors \\
\hline Tudyate & Crushing pain & JeerneAtyarthaVedana & Pain after digestion \\
\hline Diryyate & Cracking pain & & \\
\hline Nirmathyate & Piercing Pain & & \\
\hline Sphotyate & Pricking Pain & & \\
\hline Patyate & Pain like cutting by saw & & \\
\hline Shunyate & $\begin{array}{l}\text { Cardiac cramps } \\
\text { Cardiac Arrest }\end{array}$ & $\begin{array}{l}\text { Mental Symptoms: } \\
\text {-Pramoha }\end{array}$ & \\
\hline $\begin{array}{l}\text { Vesthanam } \\
\text { Stambha }\end{array}$ & & & Delirium \\
\hline
\end{tabular}




\section{DISCUSSION}

Concept of DhamaniPratichyay and GrathitaRak-

ta:

Dhamanipratichyay has been mentioned as a kaphajananatmajavikara in Charak Samhita, which results in dhamani upalepa ${ }^{4}$. The condition is quite like Atherosclerosis. Dhamanipratichyay plays an important role in the pathogenesis of Hridroga. Factors respon- sible for the genesis of Dhamanipratichyay can be summarized as below:

- Sama Meda

- VyanVata

- Kha- vaigunya of dhamani

The pathogenesis explaining the role of dhamanipratichyaya in the incidence of ischemic heart disease can be explained in terms of the schematic representation shown as below:

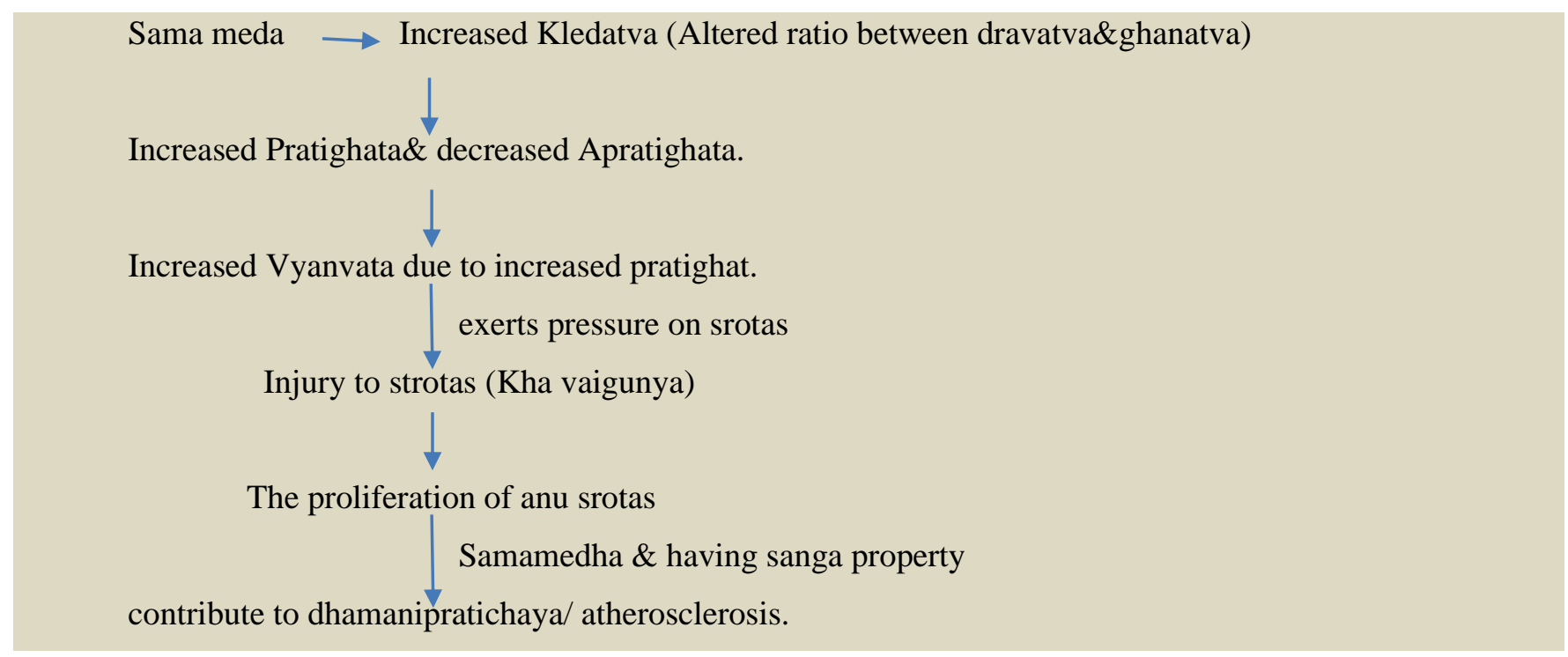

Concept of Grathita Rakta ${ }^{18}$ : Acharya Charak has mentioned about grathitarakta in the context of Raktapittachikitsa. Due to kaphaanubandhatwa (rakta in association with kapha), the density of rakta dhatu increases. We can explain it in terms of the schematic presentation as shown below: 


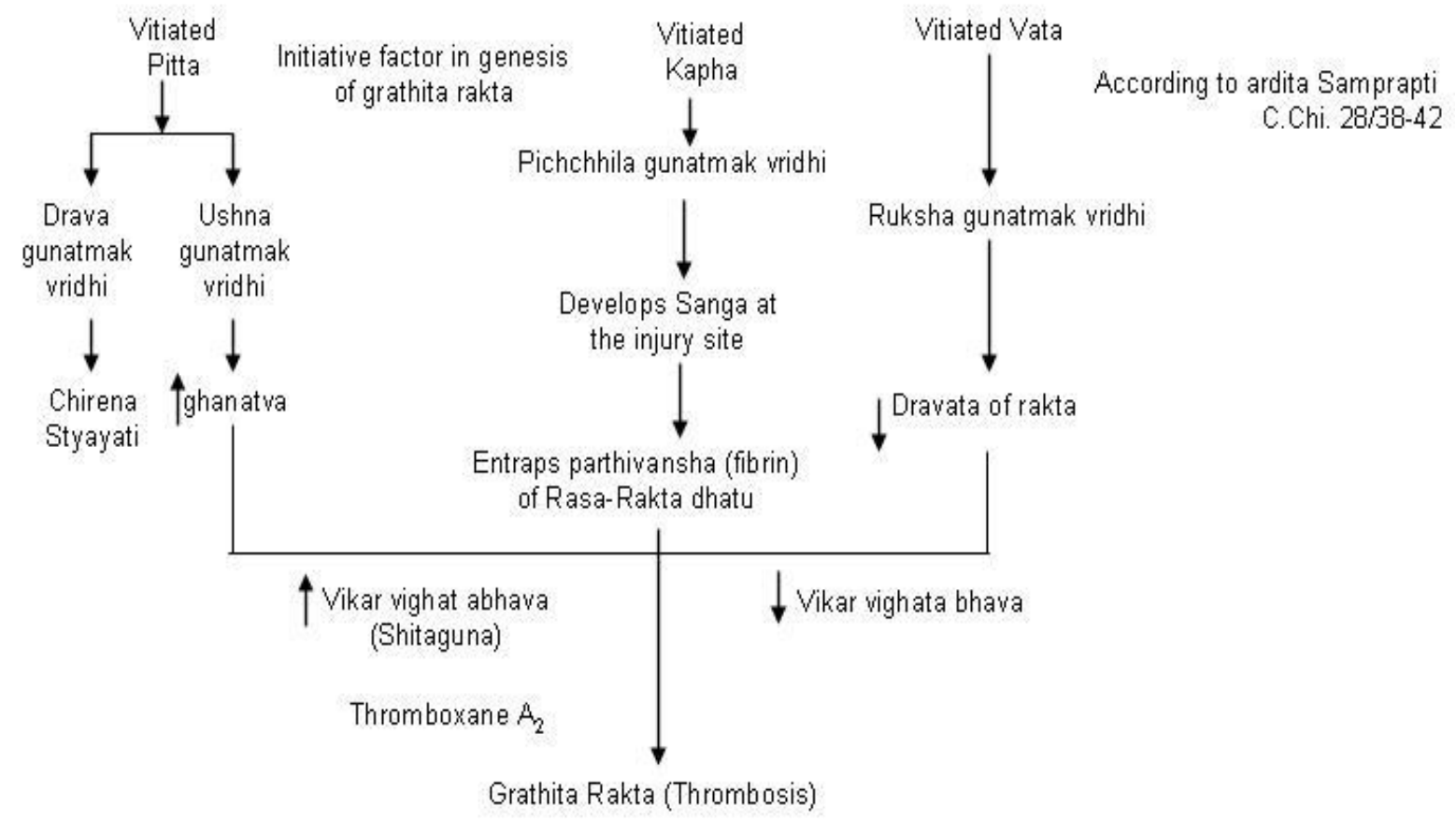

\section{Samprapti Ghatak of IHD:}

Dosa: ApanavritaVyanVata, Saman Avritaapan

Dusya: KaphanubandhaRakta, Sama Meda

Agni: Jatharagnimandata and visamata

Srota: Pranavaha, Rasavaha, Raktavaha, Medavahasrotas

Srotadusti: Sanga (Khavaigunyad)

Adhisthan: Sarvasharir

Uddhavsthana: Amasaya, Hridaya

Concept of amarasa in the pathogenesis of diabetes mellitus and IHD as explained by Ayurveda:

Adiposity and medoRoga are two important risk factors for IHD. Adiposity or MedoRoga may be Sahaja, or it may be caused by overnutrition, excessive sleep, sedentary habits, and other psychosocial factors. A large number of diseases have been classified in Ayurveda to be caused by overnutrition (Santarpanajanya). Ayurveda has emphasized the conversion of excessive sweet amarasa into meda Dhatu due to its Sneha property ${ }^{19}$, which in turn leads to the formation of PramehaRoga.

Diabetes mellitus accelerates coronary and peripheral atherosclerosis and is frequently associated with dyslipidaemias and increases in the risk of angina, myocardial infarction, and sudden coronary death.
It is useful to consider atherosclerosis in the context of alterations in the nature of the circulating blood (hyperglycaemia; increased concentrations of LDL cholesterol, tissue factor, fibrinogen, von Willebrand factor, coagulation factor VII, and platelet microparticles). The combination of a "vulnerable vessel" in a patient with "vulnerable blood" promotes a state of hypercoagulability and hypofibrinolysis. This is especially true in patients with diabetes mellitus ${ }^{20}$. This clearly explains the role of samameda and rakta dhatu along with the presence of kha-vaigunya (vulnerable vessel) in the pathogenesis of the disease IHD.

Drug therapy to prevent and manage stable ischaemic heart disease as per modern medicine: ${ }^{21}$

These include:

- antiplatelet agents.

- lipid-lowering agents, hydroxymethylglutaryl coenzyme A reductase inhibitors (statins).

- $\beta$-blockers.

- Angiotensin-converting enzyme (ACE) inhibitors are indicated in many patients with stable IHD, especially those with diabetes or left ventricular (LV) dysfunction.

Adverse effects of statin: ${ }^{22}$ 
- The risk of statin-associated myopathy is increased by the presence of older age, frailty, renal insufficiency, and co-administration of drugs that interfere with the metabolism of statins, such as erythromycin and related antibiotics, antifungal agents, immunosuppressive drugs, and fabric acid derivatives (particularly gemfibrozil).

- Another consequence of statin therapy can be an elevation in liver transaminases (alanine aminotransferase [ALT] and aspartate aminotransferase $[\mathrm{AST}])$.

Principle of treatment in to be adopted in IHD as per Ayurveda:

Role of samameda, rasa-raktavaha and pranavahasrotas, vata dosha, grathitarakta, hridaya kriya, satva, rogaatikarshana, all these factors should be considered, and then multidrug combination should be decided.

- To treat Amashita Meda: Drugs explained in Urustambha, Staulya and santarpanothavyadhichikitsa can be done.

Single Herbs: Maricha, Chitrak, Daruharidra, Rason, Tulsi, vacha, musta, pippali, kutki.

- To treat grathitarakta: The role of katu rasa pradhandravya should be studied since it has shonitasanghtabhinnati action as per Charak. Use of utpalnalkshar, priyangukshar, palashkshar, darbha, kusta.

- To treat dhamanipratichayay, kaphaghnachikitsa to be adopted.

- Single herbs acting on Rasa and raktavaha Srotas: Amalaki, haritaki, punarnava, Shatavari, Shalaparni, Sariva, Manjistha, yastimadhu, Shilajeet, Amrita, Patola, Kutki, Vidanga, laksha.

- Single herbs acting on PranavahaSrotas: Vasa, Amrita, punarnava, Amalaki, pushkarmoola, kusta, brihati, Kantakari, Haridra, Daruharidra, Bharangi, Yastimadhu, pippali, mrigasringi.

- To treat Vata dosha: Dashamoola, haritaki, Rason, guggulu, punarnava, shalaparni, shatavari, pushkarmoola, nagbala.

- Kalpaprayoga:

1. PushkarmuladiKwath

2. Hridayarnav Rasa
3. LasonadiVati

4. ShuddhaGuggulu

5. Arjunarista

6. NavayasaChurna

7. Prabhakar Vati

\section{CONCLUSION}

Ischemic heart disease is a rapidly growing health concern among both younger adults and the elderly. Progressive vascular changes owing to unhealthy dietary and lifestyle choices is the primary underlying factor behind IHD. Although modern medicine has come up with multiple treatment approaches to limit disease morbidity, it is also sometimes associated with a hazardous effect on the health of an individual. Ayurveda offers effective management of the disease with an appropriate treatment approach and healthy dietary and lifestyle modifications with a comparatively safer outcome. Hence an integrative approach adopted can significantly minimize the risk factors and control the mortality burden associated with the disease.

\section{REFERENCES}

1. Kasper, Fauci, Hauser, Longo, Jameson, Loscalzo, Harrison's Principles of Internal Medicine, Ischemic Heart Disease, published by McGraw-Hill Medical Publishing Division, New Delhi, $17^{\text {th }}$ edition,2015, Chapter 293, pg. no. 1578

2. Walsh, Fang, Fuster, Hurt's The Heart Manual of Cardiology, Management of Patients with Chronic Ischaemic Heart Disease, published by McGrawHill,13 ${ }^{\text {th }}$ edition,2001, Chapter 21, pg.no. 236

3. Ganga Sahaya Pandey, Charak Samhita Sutra Sthan 17/31, Chaukhamba Bharati Academy, Varanasi,201, pg no. 336

4. Ganga Sahaya Pandey, Charak Samhita Sutra Sthan 20/17, Chaukhamba Bharati Academy, Varanasi,2014, pg no. 405

5. Walsh, Fang, Fuster, Hurt's The Heart Manual of Cardiology, Management of Patients with Chronic Ischaemic Heart Disease, published by McGrawHill,13th edition,2001, Chapter 21, pg.no. 238

6. Walsh, Fang, Fuster, Hurt's The Heart Manual of Cardiology, Management of Patients with Chronic Is- 
chaemic Heart Disease, published by McGrawHill,13th edition,2001, Chapter 21, pg.no. 237

7. Kasper, Fauci, Hauser, Longo, Jameson, Loscalzo, Harrison's Principles of Internal Medicine, Ischaemic Heart Diseases, published by McGraw-Hill Medical Publishing Division, New Delhi,17thedition,2015, Chapter 293, pg. no. 1580

8. Kasper, Fauci, Hauser, Longo, Jameson, Loscalzo, Harrison's Principles of Internal Medicine, Ischaemic Heart Diseases, published by McGraw-Hill Medical Publishing Division, New Delhi,17thedition,2015, Chapter 293, pg. no. 1581

9. KavirajaAmbikaduttaShastri, SushrutaSamhita, Sharirsthan 4/30, Chaukhamba Sanskrit Sansthan, Varanasi,2013, pg no.487

10. Ganga SahayaPandey, Charak Samhita, NidanSthan 5/7, Chaukhamba Bharati Academy, Varanasi,2014

11. Ganga SahayaPandey, Charak Samhita, Sutra Sthan 30/3, Chaukhamba Bharati Academy, Varanasi,2014

12. Tripathi B, AstangaHridaya, Sutra Sthan 12/21. Chaukhamba Sanskrit Pratisthan, Delhi, 2015.

13. Ganga SahayaPandey, Charak Samhita, ChikitsaSthan 15/33, Chaukhamba Bharati Academy, Varanasi,2014

14. Tripathi B, AstangaHridaya, Sutra Sthan 12/13. Chaukhamba Sanskrit Pratisthan, Delhi, 2015

15. Tripathi B, AstangaHridaya, Sutra Sthan 12/15. Chaukhamba Sanskrit Pratisthan, Delhi, 2015

16. Ganga SahayaPandey, Charak Samhita, Sutra Sthan 17/31,33,35,36,37, Chaukhamba Bharati Academy, Varanasi

17. KavirajaAmbikaduttaShastri, SushrutaSamhita, uttarsthan 43/6, Chaukhamba Sanskrit Sansthan, Varanasi,2013, pg no.359

18. Ganga SahayaPandey, Charak Samhita, ChikitsaSthan 4/93, Chaukhamba Bharati Academy, Varanasi,2014 pg.no. 193

19. KavirajaAmbikaduttaShastri, SushrutaSamhita, Sutrasthan 15/38, Chaukhamba Sanskrit Sansthan, Varanasi, 2013

20. Kasper, Fauci, Hauser, Longo, Jameson, Loscalzo, Harrison's Principles of Internal Medicine, Ischaemic Heart Disease, published by McGraw-Hill Medical Publishing Division, New Delhi,17thedition,2015, Chapter 293, pg. no. 1579

21. Kasper, Fauci, Hauser, Longo, Jameson, Loscalzo, Harrison's Principles of Internal Medicine, Ischaemic Heart Disease, published by McGraw-Hill Medical Publishing Division, New Delhi,17thedition,2015, Chapter 293, pg. no. 1589
22. Kasper, Fauci, Hauser, Longo, Jameson, Loscalzo, Harrison's Principles of Internal Medicine, disorders of lipoprotein metabolism, published by McGraw-Hill Medical Publishing Division, New Delhi,17thedition,2015, Chapter 421, pg. no. 2435

\section{Source of Support: Nil \\ Conflict of Interest: None Declared}

How to cite this URL: Gitismita Borah \& Satyendra Ojha: Management Of Ischemic Heart Disease As Per Ayurveda: A Review. International Ayurvedic Medical Journal \{online\} 2021 \{cited October 2021\} Available from: http://www.iamj.in/posts/images/upload/2535_2541.pdf 